\title{
Persistence of Hemarthria and Cynodon cultivars in mob grazing in the humid tropical region of Puerto Rico'
}

\author{
Rafael Ramos-Santana and José E. Rodriguez-Arroyo"
}

\begin{abstract}
The persistence and dry forage production of nine accessions ( 8 Hemarthrias and one (ynodon) in mob grazing were measured during a 387-day period. During the short day season, accession $H$. altissima USDAPI 364888 produced the highest dry forage yield, but did not differ significantly $(P<.05)$ from the others except for $H$. altissima USDAPI 364873 and 364875. During the long-day season, $H$. altissima USDAPI 364888 again produced the highest dry forage yield, not differing significantly $(P<.05)$ from $H$, altissima 364873,364875 and 409744 and $C$. plectostachyum 341818. For the whole 387-day period, accessions $H$. altissima USDAPI 364888,364873 and 409744 and $C$. plectostachyum 341818 showed excellent yields in terms of consumed forage. However, no significant differences ( $P<.05)$ were observed among accessions during the period mentioned. Similarly although no significant differences $(P<.05)$ were observed in terms of weed infestation percentages, accessions $\boldsymbol{H}$. altissima USDAPI 364875 and $C$. plectostachyum USDAPI 341818 had higher weed infestation percentage than the other accessions. In terms of leaves to stem ratios C. plectostachyum USDAPI 341818 produced the highest percentages without differing significantly $(P<.05)$ from $H$, altissima USDAPI 364873 and 379617 .
\end{abstract}

\section{RESUMEN}

Persistencia de Hemarthria y Cynodon bajo pastoreo de manada en la zona tropical húmeda

Se midió la persistencia y la producción forrajera de nueve variedades (ocho Hemarthria y una Cynodon) bajo la técnica de pastoreo grupal durante 387 días. En la época de días cortos la variedad $H$. altissima USDAPI 364888 produjo la mayor cantidad de forraje seco sin diferir significativamente $(P<.05)$ de las demás, excepto $H$. altissima USDAPI 364873 y 364875 . En dias largos la variedad H. altissima USDAPI 364888 produjo nuevamente la más alta cantidad de forraje seco sin diferir significativamente $(P<.05)$ de $H$. altissima USDAPI 364873,364875 y 409744 y C. plectostachyum 341818. Durante todo el período de 387 días las variedades USDAPI 364888,364873 y 409744 y $C$. plectostachyum 341818 registraron excelentes producciones en término de forraje consumido. Sin embargo, no se observaron diferencias significativas $(P<.05)$ entre los cultivos durante dicho período. Aunque no se observaron diferencias significativas $(P<.05)$ en infestación por yerbajos, las variedades $\boldsymbol{H}$. alfissima 364875 y C plectostachyum USDAPI 341818 mostraron las

'Manuscript submitted to Editorial Board 5 September 1990.

${ }^{2}$ Research Assistant, Department of Agronomy.

"Research Technician, Corozal Substation. 


\begin{abstract}
mayores tasas de infestación en relación con el resto de las variedades evaluadas. En términos de la razón de hojas a tallo $C$. plectostachyum USDAPI 341818 produjo el mayar porcentaje sin diferir significativamente $(P<.05)$ de $H$. altissima USDAPI 364873 y 379617.
\end{abstract}

\title{
INTRODUCTION
}

The objective of forage germoplasm evaluation is the identification of the best accessions with a wide range of adaptation to the environment and to the different pasture management systems. In the past many cultivars were selected in view of their higher dry forage yields for grazing purposes. However, the cultivars did not always show persistency under grazing conditions (1).

In Puerto Rico few studies have been performed on the persistence of limpogxass under grazing conditions. The results of a 3-year experiment on small plots showed that cultivar $H$. altissima USDAPI 2999994 (Greenalta) produced significantly higher dry forage yields than four other grasses (6). Another study measured the response of 12 Cynodon and 8 Hemarthria cultivars under a simulated grazing technique. $\mathrm{H}$. altissima USDAPI $364881,347238,379617$ and 364873 excelled in terms of dry matter production in both short- and long-day seasons in development qualities as well as in disease, insect and weed tolerance (4). At the University of Florida a systematic evaluation of performance in small plot and grazing experiments showed Floralta $(H$. altissima USDAPI 364888 ) to be superior to other released limpo grasses in total dry matter yield. Floralta was specifically selected for persistence under grazing (3).

The present experiment is the continuation of the first 1 1/2-year experiment on the adaptation of 20 forage cultivars evaluated under the simulated grazing technique (4). The main objective of this study was to choose the best adapted accessions evaluated under grazing conditions on small plots, according to their persistence and dry forage yield during a 387-day period. The best accessions will be evaluated under more extensive conditions in future trials measuring other pasture management factors.

\section{MATERIALS AND METHODS}

The experiment was conducted at the Corozal Substation on a Corozal clay soil (Aquic Tropudults) during a 387-day period between 21 December 1988 and 12 January 1990. Total precipitation for the period was $1,888 \mathrm{~mm}$ and mean air temperature for the period was $24^{\circ} \mathrm{C}$. Soil $\mathrm{pH}$ at the beginning of the experiment was 5.5. Eight $H$. altissima accessions and one Cynodon were evaluated in a complete randomized design with four replications. During the experimental period each $12.5 \mathrm{~m}^{2}$-plot received $2,224 \mathrm{~kg} / \mathrm{ha}$ of a $15-5-10$ fertilizer broadcast in four applications.

During the long day season (24 April 1989 to 16 October 1989) the cultivars were grazed every 29 days with a group of 12 mature cows and 
10 heifers in a 0.2-ha area. During the short-day season (21 December 1988 to 24 April 1989 and 16 October 1989 to 12 January 1990) the cultivars were grazed every 42 days with a group of six mature cows and 10 heifers in a 0.2-ha area. Each grazing period lasted 8 hours.

For the determination of offer, refused and consumed dry forage, two random squares $\left(0.4 \mathrm{~m}^{2}\right.$ each) were compared with two other squares in each of the forty plots. Offered forage was determined by cutting two squares at $5 \mathrm{~cm}$ from the ground before each grazing. Refused forage was determined on the paired squares by cutting the remaining forage above $5 \mathrm{~cm}$ from the ground after each grazing. Consumed forage was determined by subtracting the amount of dry forage before and after each grazing. The refused-offer ratio (R/O) was determined.

For the determination of the leaves to stem ratios five random plants cut at $15 \mathrm{~cm}$ from the ground were selected from each plot before the last grazing. The weed infestation percentage in each plot at the end of the 387-day period was determined visually.

\section{RESULTS AND DISCUSSION}

Table 1 presents the mean dry forage grazing estimates of Hemarthria and Cynodon cultivars for a 6-week harvest period during the short-day season. Dry matter offer expressed as kilogxams per hectare is an important measurement in grazing studies and is closely related to animal production under extensive conditions (2). Accession Floralta (USDAPI 364888) showed the highest dry matter offer, not differing

TABLE 1.-Mean dry forage grazing estimates for Hemarthria and Cynodon accessions at six weeks of harvest during shoit day season (21 December 1988 to 24 April 1989 and 16 October 1989 to 12 January 1990)

\begin{tabular}{lccccc}
\hline Name & USDAPI & Offer & Refused & Consumed & R/O' \\
\hline & & $k g / h a$ & $k g / h a$ & $k g / h a$ & $\%$ \\
H. altissima & 364888 & $16,643 \mathrm{a}^{2}$ & $6,657 \mathrm{a}$ & $9,986 \mathrm{a}$ & $41 \mathrm{a}$ \\
H. altissima & 364873 & $14,760 \mathrm{ab}$ & $6,657 \mathrm{a}$ & $8,103 \mathrm{ab}$ & $46 \mathrm{a}$ \\
H. altissima & 364875 & $13,180 \mathrm{abc}$ & $5,884 \mathrm{ab}$ & $7,296 \mathrm{ab}$ & $47 \mathrm{a}$ \\
H. altissima & 364881 & $12,608 \mathrm{bc}$ & $4,438 \mathrm{bc}$ & $8,170 \mathrm{ab}$ & $37 \mathrm{a}$ \\
H. altissima & 409744 & $12,037 \mathrm{bc}$ & $5,615 \mathrm{abc}$ & $6,422 \mathrm{ab}$ & $43 \mathrm{a}$ \\
C. plectostachyum & 341818 & $11,331 \mathrm{bc}$ & $4,438 \mathrm{bc}$ & $6,893 \mathrm{ab}$ & $42 \mathrm{a}$ \\
H. altissima & 364889 & $10,490 \mathrm{c}$ & $3,732 \mathrm{c}$ & $6,758 \mathrm{ab}$ & $34 \mathrm{a}$ \\
H. altissima & 379617 & $10,288 \mathrm{c}$ & $4,505 \mathrm{bc}$ & $5,783 \mathrm{~b}$ & $43 \mathrm{a}$ \\
H. altissima & 347238 & $9,784 \mathrm{c}$ & $4,438 \mathrm{bc}$ & $5,346 \mathrm{~b}$ & $51 \mathrm{a}$ \\
Mean & & 12,347 & 5,151 & 7,195 & 43 \\
\hline
\end{tabular}

'Acceptability index $=\mathrm{R} / \mathrm{O}=\frac{\mathrm{kg} \text { of dry forage refused }}{\mathrm{kg} \text { of dry forage offered }} \times 100$

"Means on the same column followed by the same letters do not differ statistically at the $5 \%$ probability level. 
significantly $(\mathrm{P}<.05)$ from only $H$. altissima USDAPI 364873 and 364875. On the other hand, cultivar 364875 had the highest weed infestation percentage (19\%). This accession can be considered as somewhat less well adapted because of its lower weed tolerance (4). The high performance of 364888 and 364873 is an interesting result because of the low productivity most tropical forages show during short-day season in the humid regions of Puerto Rico (6).

Refused forage is another important measurement in the determination of the efficient utilization of pastures. The greater amount of refused forage on lighter stockings during the rainy season is often associated with a reduction in animal performance (5). Also the lower refused forage levels in short-day seasons or the higher stocking rates in any season may considerably reduce the efficient utilization of the pastures (6). The data in table 1 show that most of the accessions with higher offer levels (364888, 364873, 364875 and 409744) showed higher refused forage levels even though the differences were not always significant $(\mathrm{P}<.05)$. In terms of the refuse-offer ratio $(\mathrm{R} / \mathrm{O})$ no significant $(\mathrm{P}<.05)$ differences were observed among any of the grasses on evaluation. This means that the proportion of residual forage as a function of the total available forage (offered forage) was not considerably different among the accessions. Thus few differences are expected in forage acceptability among accessions under similar conditions. This fact is also supported by the lack of significant differences $(\mathrm{P}<.05)$ between most accessions in terms of consumed forage.

Table 2 shows the mean dry forage grazing estimates for the accessions harvested every 4 weeks during long-day season. Again, cultivar Floralta (364888) continued to be the most productive grass in terms of forage offer, although not significantly different $(\mathrm{P}<.05)$ from $H$. altissima $364873,364875,341818$ and 409744 . As before, the most productive accessions in forage offer tended to have higher refused forage levels. No significant differences $(P<.05)$ were observed in terms of consumed forage and the $\mathrm{R} / \mathrm{O}$ ratio, so that an even acceptability of the accessions was observed under the season conditions.

Table 3 presents the mean total dry forage grazing estimates and leaves to stem ratios for the accessions under evaluation during the 387day period of the trial. Floralta (364888) produced the highest forage offer without differing significantly $(\mathrm{P}<.05)$ from $H$. altissima 364873 , 364875 and 409744 and C. plectostachyum 341818. Similarly, in terms of consumed forage accessions $H$. altissima $364888,364873,409744$ and $C$. plectostachyum 341818 showed yields of more than $16,500 \mathrm{~kg} / \mathrm{ha}$, although no significant differences $(\mathrm{P}<.05)$ were observed among accessions. These four accessions showed low weed infestation percentages and high persistence during the above mentioned period. On the other hand, C. plectostachyum 341818 presented higher weed infestation per- 
TABI,E, 2.-Mean dry forage grazing estimutes for Hemarthria and Cynodon accessions at four weeks of harvest during long days season (24. April 1989 to 16 October 1989)

\begin{tabular}{lccccc}
\hline Name & USDAPI & Offer & Refused & Consumed & R/O \\
\hline & & $k g / h a$ & $k g / h a$ & $k g / h a$ & $\%$ \\
$H$. altissima & 364888 & $21,687 \mathrm{a}^{2}$ & $12,071 \mathrm{a}$ & $9,616 \mathrm{a}$ & $55 \mathrm{a}$ \\
H. altissima & 364873 & $17,215 \mathrm{ab}$ & $8,137 \mathrm{abc}$ & $9,078 \mathrm{a}$ & $45 \mathrm{a}$ \\
H. altissima & 364875 & $19,232 \mathrm{ab}$ & $11,264 \mathrm{ab}$ & $7,968 \mathrm{a}$ & $59 \mathrm{a}$ \\
H. altissima & 364881 & $14,054 \mathrm{~b}$ & $6,590 \mathrm{bc}$ & $7,464 \mathrm{a}$ & $46 \mathrm{a}$ \\
H. altissima & 409744 & $19,030 \mathrm{ab}$ & $8,775 \mathrm{abc}$ & $10,255 \mathrm{a}$ & $45 \mathrm{a}$ \\
C. plectostachyum & 341818 & $18,963 \mathrm{ab}$ & $9,347 \mathrm{abc}$ & $9,616 \mathrm{a}$ & $48 \mathrm{a}$ \\
H. altissima & 364889 & $13,684 \mathrm{~b}$ & $5,346 \mathrm{c}$ & $8,338 \mathrm{a}$ & $38 \mathrm{a}$ \\
H. altissima & 379617 & $14,054 \mathrm{~b}$ & $5,581 \mathrm{c}$ & $8,473 \mathrm{a}$ & $41 \mathrm{a}$ \\
$H$. altissima & 347238 & $14,727 \mathrm{~b}$ & $6,355 \mathrm{bc}$ & $8,372 \mathrm{a}$ & $43 \mathrm{a}$ \\
Mean & & 16,961 & 8,163 & 8,798 & 47
\end{tabular}

'Acceptability index $=\mathrm{R} / \mathrm{O}=\frac{\mathrm{kg} \text { dry forage refused }}{\mathrm{kg} \text { dry forage offered }} \times 100$

${ }^{2}$ Means on the same column followed by the same letters do not differ statistically at the $5 \%$ probability level.

centages and thus lower persistence but without statistical significance $(\mathrm{P}<.05)$.

These results agree with those of Quesenberry et al. (3) on mob grazing experiments of intermediate level evaluations. The studies showed that for 3-, 5-, 7- and 9-week defoliation intervals, Floralta (364888) remained near $80 \%$ ground cover after 3 years of grazing, thus showing

TARLE 3.-Mean total dry forage grazing estimates, leaves to stem ratios (L/S) and weed infestation percent for Hemarthria and Cynodon accessions during the 387-day period from 21 December 1988 to 12 January 1990

\begin{tabular}{lcccccc}
\hline Name & USDAPI & Offer & Refused & Consumed & L/S & $\begin{array}{c}\text { Weed } \\
\text { infestation }\end{array}$ \\
& & $k g / h a$ & $k g / h a$ & $k g / h a$ & $\%$ & $\%$ \\
H. altissima & 364888 & $38,330 \mathrm{a}$ & $18,728 \mathrm{a}$ & $19,602 \mathrm{a}$ & $17 \mathrm{c}$ & $6 \mathrm{a}$ \\
H. altissima & 364873 & $31,975 \mathrm{ab}$ & $14,794 \mathrm{abc}$ & $17,181 \mathrm{a}$ & $25 \mathrm{ab}$ & $6 \mathrm{a}$ \\
H. altissima & 364875 & $32,412 \mathrm{ab}$ & $17,148 \mathrm{ab}$ & $15,264 \mathrm{a}$ & $16 \mathrm{c}$ & $19 \mathrm{a}$ \\
H. altissima & 364881 & $26,663 \mathrm{~b}$ & $11,028 \mathrm{bc}$ & $15,635 \mathrm{a}$ & $21 \mathrm{bc}$ & $6 \mathrm{a}$ \\
H. altissima & 409744 & $31,067 \mathrm{ab}$ & $14,390 \mathrm{abc}$ & $16,677 \mathrm{a}$ & $23 \mathrm{bc}$ & $8 \mathrm{a}$ \\
H. altissima & 364889 & $24,175 \mathrm{~b}$ & $9,078 \mathrm{c}$ & $15,097 \mathrm{a}$ & $17 \mathrm{c}$ & $9 \mathrm{a}$ \\
H. altissima & 379617 & $24,343 \mathrm{~b}$ & $10,087 \mathrm{c}$ & $14,256 \mathrm{a}$ & $27 \mathrm{ab}$ & $6 \mathrm{a}$ \\
H. altissima & 347238 & $24,511 \mathrm{~b}$ & $10,793 \mathrm{c}$ & $13,718 \mathrm{a}$ & $15 \mathrm{c}$ & $14 \mathrm{a}$ \\
C. plectostachyum & 341818 & $30,294 \mathrm{ab}$ & $13,785 \mathrm{abc}$ & $16,509 \mathrm{a}$ & $32 \mathrm{a}$ & $14 \mathrm{a}$ \\
Mean & & 29,308 & 13,314 & 15,993 & 21 & 10 \\
\hline
\end{tabular}

'Means on the same column followed by the same letters do not differ statistically at the $5 \%$ probability level. 
superiority over eight different limpo grasses. Also dry matter yields taken before each grazing showed Floralta yielded more than Bigalta (a released limpo gxass) at all grazing frequencies.

Table 3 shows the leaves to stem ratios of each of the nine accessions. Accession C. plectostachyum 341818 produced the highest leaves to stem ratio without differing significantly $(\mathrm{P}<.05)$ from $H$. altissima 364873 and 379617 . The rest of the Hemarthria accessions were significantly $(\mathrm{P}<.05)$ inferior to $C$. plectostachyum 341818 .

\section{LITERATURE CITED}

1. Mott, G. O., 1983. Evaluación del germoplasma forrajero bajo diferentes sistemas de manejo del pastoreo. Germoplasma forrajero bajo pastoreo en pequeñas parcelas. Metodologia de evaluación, memorias de una reunión de trabajo, Cali, Colombia, septiembre 22-24, 1982. RIEPT, CIAT, pág. 149-50. Editadas por Osvaldo Paladines y Carlos Lascano.

2. Paladines, O. y C. Lascano, 1983. Recomendaciones para evaluar germoplasma bajo pastoreo en pequeñas parcelas. Metodologia de evaluación, memorias de una reunión de trabajo, Cali, Colombia, septiembre 22-24, RIEPT, ClAT, pág. 181. Editadas por Osvaldo Paladines y Carlos Lascano.

3. Quesenberry, K. H., W. R. Ocumpaugh, O. C. Ruelke, L. S. Dunarin and P. Mislevy, 1984. Floralta - A limpograss selected for yield and persistence in pastures. Agric. Exp. Stn., Univ. Fla., Gainesville. Circular S-312, P. 1-16.

4. Ramos, R. and $J$. E. Rodriguez, 1990. Use of a simulated grazing technique for the evaluation of tropical grasses. J. Agric. Univ. P. R. 74 (1): 51-9.

5. Tergas, L. E., 1983. Efecto del manejo del pastoreo en la utilización de la pradera tropical. Germoplasma forrajero bajo pastoreo en pequeñas parcelas. Metodología de evaluación, memorias de una reunión de trabajo, Cali, Colombia, septiembre 22-24, RIEPT, CIAT, pág. 70-71. Editadas por Osvaldo Paladines y Carlos Lascano.

6. Vicente-Chandler, J., R. Caro Costas, F. Abruña and S. Silva, 1983. Producción y utilización intensiva de las forrajeras en Puerto Rico. Esta. Exp. Agríc. P. R., Bol. 271. 